\title{
The effect of fibronectin derived fibrin-binding peptide fragments on periodontal ligament cell migration : an in vitro wound healing model
}

Sang-hyun Yea, Junhwan Kim, Young Ku, In-Chul Rhyu, Ki-Tae Koo, Tae-Il Kim, Yang-Jo Seol,

Department of Periodontology, School of Dentistry, Seoul National University

\section{Abstract}

One of the major components of ECM is fibronectin (FN), a large glycoprotein, which interacts with cells and transmits signals through numerous receptors. FN mediates a wide variety of cellular interactions with ECM and plays important roles in cell adhesion, migration, proliferation, and

differentiation. By means of Scratch wound assay using synthetic oligopeptide, the effect of each fragments on cell migration was investigated.

\section{Background and Aim}

Aim of the study is to examine the effect of synthetic FN fragments including fibrin binding sites on migration of osteoblast-like cells via in vitro scratch assay.

\section{Methods and Materials}

- MC3T3-E1 osteoblast-like cells

- Synthetic oligopeptide

FF1(CYDNGKHYQ), FF3(CFDKYTGNTYR),

FF5(CTSRNRCNDQ)

- diluted to 50,100 and $150 \mu \mathrm{M}$

- coated to 4-well cell culture plate

\section{- Scratch wound assay}

$-1 \times 10^{5}$ cells/well

- parallel scratches with $200 \mu l$ plastic pipette tips

pretreated with mitomycin $\mathrm{C}(30 \mu \mathrm{g} / \mathrm{ml})$

$1 \mathrm{hr}$ before wounding

\section{- Fixation and Staining}

- 14, $20 \mathrm{hr}$ after wounding with Multiple stain

- Migration rate (\%) $=$ area of migrated cells $(A) /$ cell free area $(A+B)$
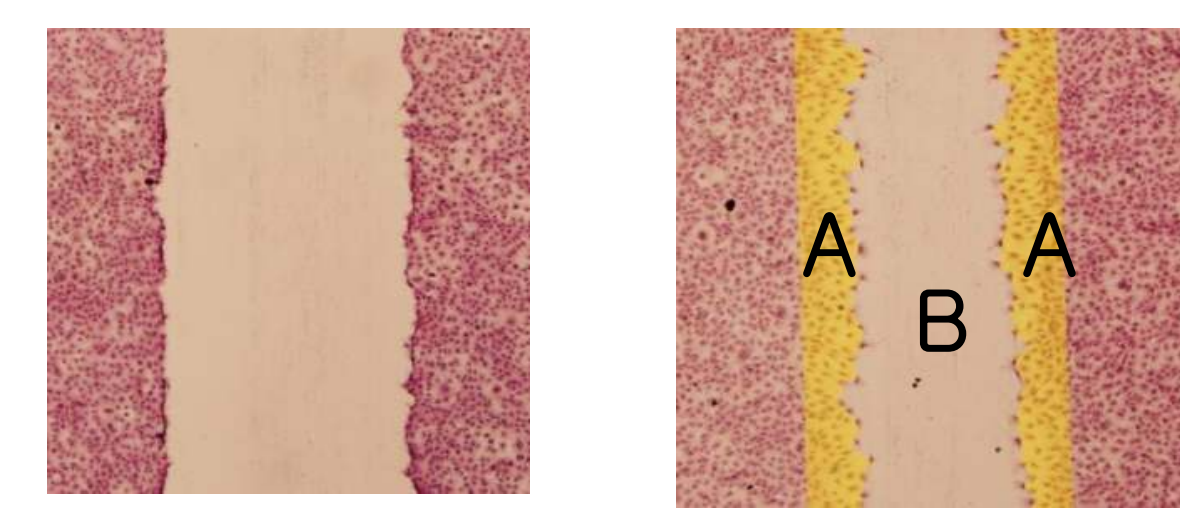

\section{Results}
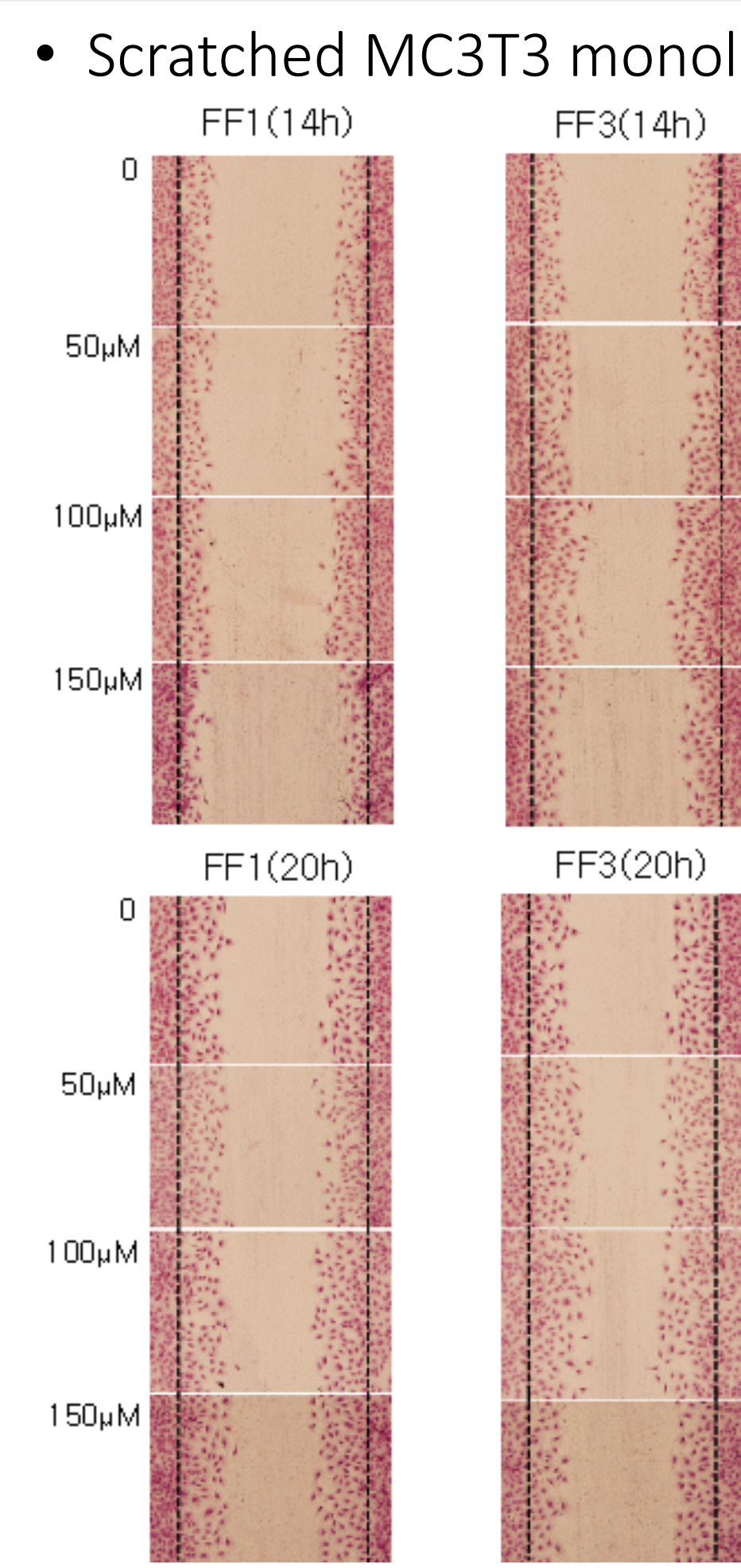

- Migration rate (\%)

\begin{tabular}{cccccc}
\hline peptide & conc. $(\mu \mathrm{M})$ & $14 \mathrm{~h}(\%)$ & $\mathrm{p}$-value & $20 \mathrm{~h}(\%)$ & $\mathrm{p}$-value \\
\hline Control & 0 & $23.5 \pm 1.2$ & & $33.8 \pm 3.0$ & \\
\hline & 50 & $26.1 \pm 1.6$ & $0.038^{*}$ & $36.3 \pm 3.7$ & 0.430 \\
FF1 & 100 & $29.6 \pm 2.3$ & $0.000^{*}$ & $38.4 \pm 3.4$ & $0.049^{*}$ \\
& 150 & $21.5 \pm 1.8$ & 0.125 & $43.7 \pm 3.2$ & $0.000^{*}$ \\
\hline \multirow{4}{*}{ FF3 } & 50 & $31.7 \pm 1.4$ & $0.000^{*}$ & $36.4 \pm 2.6$ & 0.390 \\
& 100 & $35.1 \pm 1.5$ & $0.000^{*}$ & $44.7 \pm 4.4$ & $0.000^{*}$ \\
& 150 & $28.7 \pm 3.5$ & $0.000^{*}$ & $34.0 \pm 2.5$ & 0.999 \\
\hline \multirow{2}{*}{ FF5 } & 50 & $33.6 \pm 2.1$ & $0.000^{*}$ & $39.3 \pm 4.0$ & $0.006^{*}$ \\
& 100 & $35.1 \pm 2.3$ & $0.000^{*}$ & $47.6 \pm 2.6$ & $0.000^{*}$ \\
& 150 & $25.2 \pm 1.6$ & 0.274 & $29.6 \pm 2.1$ & $0.042^{*}$ \\
\hline
\end{tabular}

$14 h$

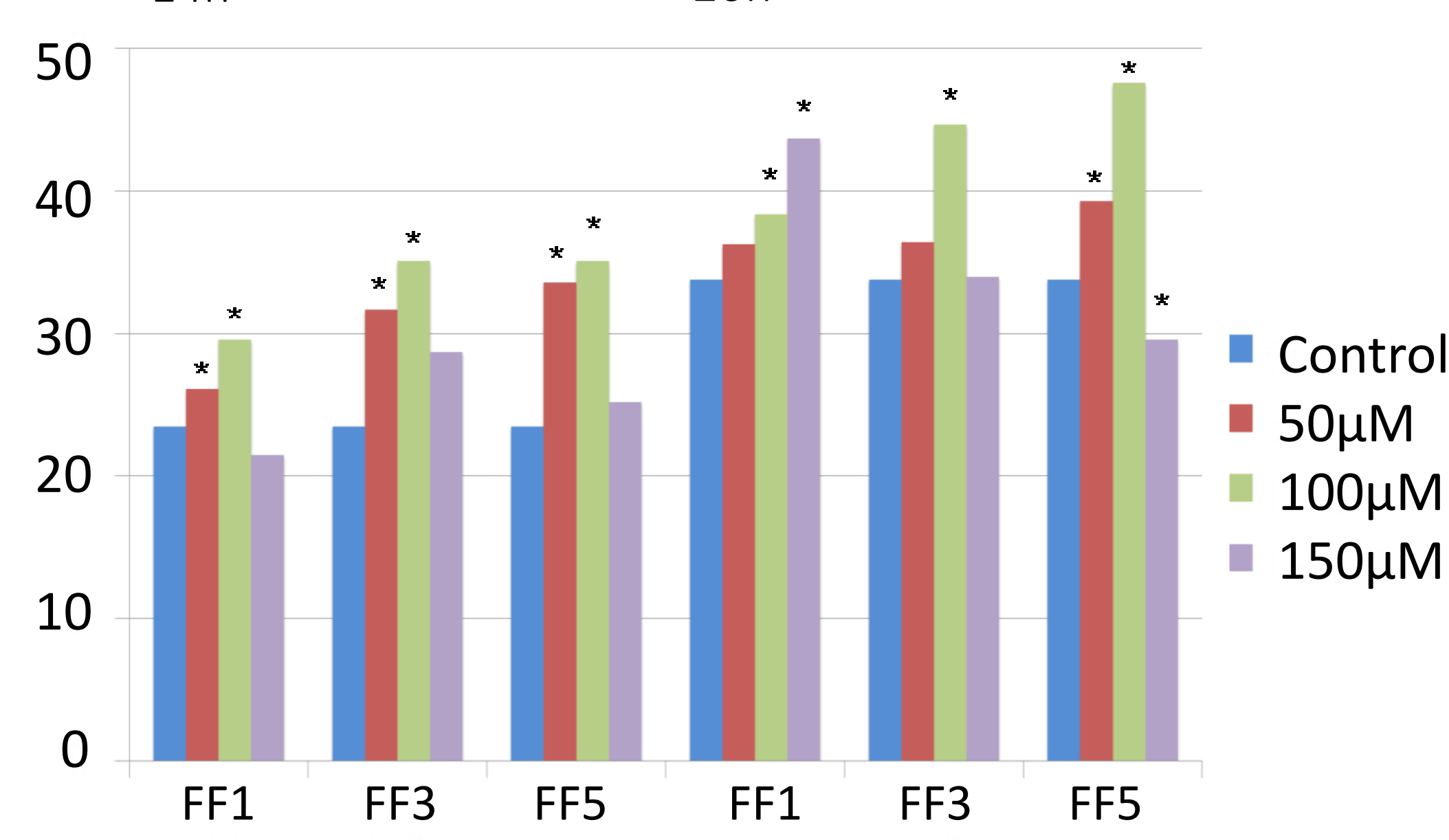

$\mathrm{n}=8$, *significantly different from control $(\mathrm{p}<0.05)$

All peptide groups except $150 \mu \mathrm{M}$ showed statistically significant increase in migration rate at $14 \mathrm{hr}$.

At $20 \mathrm{hr}$ all experimental groups of $100 \mu \mathrm{M}$ and FF1 of $150 \mu \mathrm{M}$ concentration were significantly improved the scratch closure.

Significantly increased migration was observed at type I repeats 2-5 fibrin-binding fragments of FN - FF3 and FF5 - added MC3T3-E1 cells. Optimum concentration was $100 \mu \mathrm{M}$.

The biologic effect of fibrin-binding oligopeptide in this study supports the FN's essential contribution in bone regeneration as a temporary scaffold in $\mathrm{FN}$-fibrin matrix.

\section{Conclusions}

Fibrin-binding oligopeptides, $100 \mu \mathrm{M}$ of FF3 and FF5, derived from FN enhanced the migration rate of MC3T3-E1 osteoblastlike cells in in vitro wound healing model and these peptdies can be applied to enhance the early wound healing capacity of biomaterials inserted into a bone.

\section{References}

1. Daley WP, Peters SB, Larsen M. Extraceullular matrix dynamics in development and regenerative medicine. $J$ Cell Sci 2008 Feb 1;121(Pt3):255-261.

2. Mao Y, Schwarzbauer Jf,. Fibronectin fibrillogenesis, a cell-mediated matrix assembly process. Matrix Biol 2005 Sep;24(6):389-399

3. Redick SD, Settles DL, Briscoc G, Erickson IIP. Defining fibronectin's cell adhesion synergy site by site-directed mutagenesis. J Cell Biol 2000 Apr 17;149(2):521-527. 